


\title{
Judicial Control over the Observance of Human Rights and Freedoms during the Detention of a Person
}

\author{
DOI: https://doi.org/10.46398/cuestpol.3969.40
}

\author{
Elizaveta Kuzmichova-Kyslenko * \\ Maryna Horodetska ** \\ Iryna Smal *** \\ Dariia Hurina **** \\ Myroslav Pototskyi ${ }^{* * * * *}$
}

\begin{abstract}
The purpose of this study was to identify problems in performing the functions of the investigating judge related to the protection of human rights and freedoms during detention and to offer solutions to them. The study is based on the use of methods of sampling and prognosis; system approach; descriptive statistics; comparison and collation; descriptive analysis method. We found out that the restriction of certain rights and freedoms of a person, detained on suspicion of having committed a crime, is quite legitimate, but some rights are violated due to abuse of police authority. The right to liberty and the right to security of person, the right to effective remedy and fair trial, and the right to respect for private and family life are most often violated during detention. Judicial control should be carried out in compliance with the following principles: immediacy, automaticity, conducting trial proceedings within a reasonable time. In order to universalize judicial control over the protection of human rights and freedoms during detention, we propose to develop an international legal document, regulating the conduct of judicial
\end{abstract} control.

* Senior Lecturer of the Department of Criminal Procedure, National Academy of Internal Affairs. ORCID ID: https://orcid.org/oooo-00o3-3212-5652. Email: grenada.versage23@gmail.com

** Associate Professor of Department of Organization of Pre-trial Investigation of Kryvyi Rih Educational and Scientific Institute, Donetsk Law Institute of the Ministry of Internal Affairs of Ukraine, PhD in Law. ORCID ID: https://orcid.org/oooo-0002-3228-6299. Email: loskutovagorodetskaya17@gmail. com

*** Associate Professor of Department of Theory of State, Law and Phylosophy, Faculty of Law, Private Higher Educational Establishment "Academician Stepan Demianchuk International University of Economics and Humanities”, PhD in Philosophical Sciences. ORCID ID: https://orcid.org/ooooooo2-0278-3972. Email: Raisa_Academiya@ukr.net

**** Deputy head of the Laboratory of educational and scientific work of State Scientific Reserch Forensic Centre of the Ministry of Internal Affairs of Ukraine, PhD in Law. ORCID ID: https://orcid.org/oooo0002-4613-8561. Email: dariya.hurina17@gmail.com

***** Postgraduate student in Donetsk Law Institute of the Ministry of Internal Affairs of Ukraine. ORCID ID: https://orcid.org/oooo-0oo2-2979-9114. Email: myropotocki@gmail.com

Recibido el 15/03/2021 Aceptado el 20/06/2021 
Elizaveta Kuzmichova-Kyslenko, Maryna Horodetska, Iryna Smal, Dariia Hurina y Myroslav Pototskyi

Keywords: judicial control; investigating judge; pre-trial investigation; human right; detention of a person.

\section{Control judicial sobre la observancia de los derechos humanos y las libertades durante la detención de una persona}

\section{Resumen}

El objetivo de este estudio fue identificar problemas en el desempeño de las funciones del juez de instrucción relacionadas con la protección de los derechos humanos y las libertades durante la detención para ofrecerles soluciones. El estudio se basa en el uso de métodos de muestreo y pronóstico: aproximación del sistema; estadísticas descriptivas; comparación y colación; método de análisis descriptivo. Descubrimos que la restricción de ciertos derechos y libertades de una persona, detenida por sospecha de haber cometido un delito, es bastante legítima, pero algunos derechos son violados por abuso de autoridad policial. El derecho a la libertad y el derecho a la seguridad de la persona, el derecho a un recurso efectivo y a un juicio justo y el derecho al respeto de la vida privada y familiar se violan con mayor frecuencia durante la detención. Se concluye que el control judicial debe realizarse de acuerdo con los siguientes principios: inmediatez, automaticidad, desarrollo del proceso judicial en un plazo razonable. Con el fin de universalizar el control judicial sobre la protección de los derechos humanos y las libertades durante la detención, proponemos además desarrollar un documento legal internacional que regule la conducción del control judicial.

Palabras clave: control judicial; juez de instrucción; instrucción preliminar; derechos humanos; detención de una persona.

\section{Introduction}

Human rights and freedoms are recognized as the highest value at both national and international levels (Ren, 2017). That is why fundamental rights and freedoms are the main object of protection of any democratic constitutional state. Therefore, the development of new, more effective means of ensuring these rights, is still relevant in the studies of various branches of jurisprudence. 
As stated in the Convention for the Protection of Human Rights and Fundamental Freedoms (thereinafter - the Convention) (Wikipedia, 2021) and in The Universal Declaration of Human Rights (thereinafter - the Declaration) (United Nations, 2021), all people have equal rights, that is to say, the law equally protects fundamental human rights and freedoms of people, regardless of their personal and social characteristics. In light of this, it ought to be noted that both victims of crime and the persons, suspected of having committed a crime, have equal rights. Following this line of reasoning, the main task of the entire system of criminal proceedings is, should the need arise, to provide each person, subjected to the criminal proceeding, with a real opportunity to protect his/her rights and freedoms, at any procedural stage (Jackson and Summers, 2018).

But in reality, we often face with the fact that the rights and freedoms of the offenders (especially those, who have already committed a crime) may be secured somewhat worse than the rights of other participants of criminal proceedings, such as victims, witnesses, etc., because the offender is credited with negative characteristics, associated with his antisocial and criminal behaviour (Landina, 2017). For this reason, national legislation enshrines not only the rights of everyone without exception, but also guarantees to ensure the rights of certain categories of persons, in particular the ones, who have been detained on suspicion of having committed a crime. In addition, it is necessary that authorised persons should be appointed at the legislative level in order to perform the function of supervising the observance of human rights during detention as a stage of pre-trial investigation.

The paper puts emphasis on the fact that some rights may be violated during the detention of a person, namely the right to counsel (the right to defence in pre-trial proceedings) (Soo, 2016), the right to privacy during searches and taking of evidence in the pre-trial stage (Đurđević, 2016), the right to information (if, at the time of arrest, the person is not informed of his/her rights and the reasons for his/her arrest), the right to silence, etc (Nastiuk et al., 2020; Allegrezza and Covolo, 2013).

At the same time, the detention of a person, suspected of committing a crime, requires certain coercive measures, which provide for administration of restrictions on human rights and freedoms on legal grounds. Current trends in the development of national legislation, including criminal procedure legislation, tend to implement basic international legal principles ensuring the protection of human rights and freedoms (Billing, 2016). Therefore, considerable attention is currently paid to judicial control over the observance of human rights in pre-trial proceedings, including during the detention of a person.

In order to exercise control over the provision of fundamental rights and freedoms of a person during detention, procedural legislation of 
Elizaveta Kuzmichova-Kyslenko, Maryna Horodetska, Iryna Smal, Dariia Hurina y Myroslav Pototskyi

646

Judicial Control over the Observance of Human Rights and Freedoms during the Detention of a Person

certain countries provides for the institution of an investigating judge, who carries out this judicial control (Rossinskiy, 2017). The institution of an investigating judge provides additional guarantees for the observance of fundamental human rights in criminal proceedings, which ensures due course of law in legal suits (Sharenko, 2020). In general, attention is focused on the problems of legislative control of the activities of the investigating judge in the performance of his procedural obligations to ensure the rights and freedoms of a person, detained on suspicion of having committed a crime (Brants and Franken, 2009).

The practical significance of studying the problem of judicial control over the observance of human rights and freedoms during the detention of a person is also accentuated by the fact that we have found very few works, dedicated to this issue, most of which deal with it only cursorily in the analysis of judicial control at the stage of pre-trial investigation. Thus the functions of the investigating judge are considered through the prism of the analysis of human rights and their violation during detention or notification of suspicion of committing a crime (Bakyt, 2016); in the analysis of certain human rights that are violated at different stages of criminal proceedings (Yednak et al., 2020). Special attention is paid to the protection of children's rights in criminal proceedings in cases of suspicion of a wrongdoing or detention (Mitsilegas, 2019), but with no particular focus on the role of the investigating judge in these proceedings.

The research papers have not given consideration to the risks of introducing the institution of an investigating judge (Radić, 2018), as malpractice may occur in this sphere of activities, which shall be taken into account when investigating the facts of misconduct by the investigating judge (Nagy, 2016), in particular regarding restrictions on the right of property (Muzychenko, 2017). Attention is given to the weaknesses of the activities of the investigating judge in the protection of human rights in pretrial investigations (Kostin, 2015).

Instead, despite the importance of carrying out judicial control at the national level, the main problems under investigation are almost complete lack of rigorous research of the institution of judicial control and the role of investigating judges, which they taken on with the purpose of enforcement of human rights and freedoms during detention. And, since the detention of a person limits such fundamental rights as the right to liberty and the right to privacy, it is necessary to develop a clear and explicit mechanism for the implementation of the task of the investigating judge to exercise judicial control.

The purpose of the article. Given the above, the purpose of this study is to identify problems in performing the functions of the investigating judge related to the protection of human rights and freedoms during detention and to develop ways to solve them. To that end, we will carry out the analysis 
of theoretical provisions and criminal procedural legislation of individual states concerning carrying out judicial control.

\section{Methodology and methods}

This study was carried out by stages, based on the logic of presentation of the material, in order to achieve the goals and objectives set in the article. These stages included: the search and selection of literary source base; analysis of the material, presented in the selected literary sources and evaluation of the results of these studies; identification of unsolved problems in the field of judicial control over the observance of rights and freedoms during the detention of a person; determination of the purpose of the article; formulation of conclusions and practical recommendations for solving the issues under study; outlining prospects for further research in this area.

This study used statistics on the level of legal recourses to the European Court of Human Rights (thereinafter - ECtHR) regarding violations of human rights and freedoms during detention in individual countries; the data on fundamental human rights and freedoms that may be violated during the detention of a person; the decisions of the ECtHR on violations of human rights and freedoms during detention, enshrined in the Convention; the analysis of criminal procedural norms of criminal procedure legislation of different countries regulating the work of investigative judges. We have taken into account the data on the number of judicial recourses to the ECtHR by the citizens of different countries (the countries with the lowest and the highest rates were selected), since the analysis of these data makes it possible to assess the effectiveness of criminal procedure legislation of individual countries on the enforcement of the rights and freedoms of the persons, detained on suspicion of having committed a crime.

The empirical basis of the study were the decisions of the ECtHR on violations of the provisions of Articles 5, 6 and 13 of the Convention, which may be violated in cases of arbitrary detention or detention of a person in violation of existing law (27 cases were analyzed). We have examined the norms of the criminal law enforcement codes of 38 countries for analysis of the provisions of the national criminal procedure legislation, which determine the procedure for exercising judicial control over the observance of human rights during the detention of a person, suspected of committing a crime.

To reach the goal, the following methods were used in this study: the method of systematic approach was used to study judicial control over the observance of human rights and freedoms of people in detention as the system of interrelated and interdependent procedural mechanisms and 
Elizaveta Kuzmichova-Kyslenko, Maryna Horodetska, Iryna Smal, Dariia Hurina y Myroslav Pototskyi

to develop suggestions for improving statutory regulation of the work of the investigating judge; the method of descriptive statistics, which was used for processing, systematization and visual demonstration in the form of tables of basic statistical indicators on violations of human rights and freedoms in pre-trial proceedings; the method of comparison and matching was used in order to establish logical patterns affecting the quantitative indicators of violations of human rights and freedoms during detention; the method of descriptive analysis was used to systematize, classify and synthesize information on possible offenses, risks and weaknesses of the activities of the investigating judge aimed at the protection of human rights in prejudicial inquiries; the sampling method was used to select the decisions of the ECtHR on violations of human rights and freedoms during detention as the stage of prejudicial inquiry; the prognosis method was used to develop suggestions and recommendations for improving statutory regulation of procedural activities of the investigating judge.

\section{Results of the research}

Detention of a person suspected of committing a crime is, in essence, depriving him/her of his/her right to freedom of movement and to commit certain actions, primarily aimed at fleeing the scene of a crime. That is, it is certain restriction of the rights of such a person in connection with his/her illegal (criminal) behavior.

A detainee, alleged to have committed a crime, is entitled, like any other person, to all the rights and freedoms clearly set forth in national and international laws and regulations, as was mentioned above. At the same time, application of certain repressive measures by the authorized state agencies as the occasion requires (for example, detention, arrest, keeping in custody, etc.) is associated with the violation of a number of fundamental human rights and freedoms, aimed primarily at disciplinary and correctional treatment of the offender. Herewith, the restriction of certain rights and freedoms is quite legitimate (as it is carried out for the benefit of society and in the public interest as a whole), and some rights are violated due to abuse of police authority. Based on the analysis of legislation and the court practice of the European Court of Human Rights, it was found that a number of human rights and freedoms are quite often violated during detention (see Figure 1), although their list is not exhaustive. 
Figure 1. Human rights and freedoms that may be violated during the detention of a person

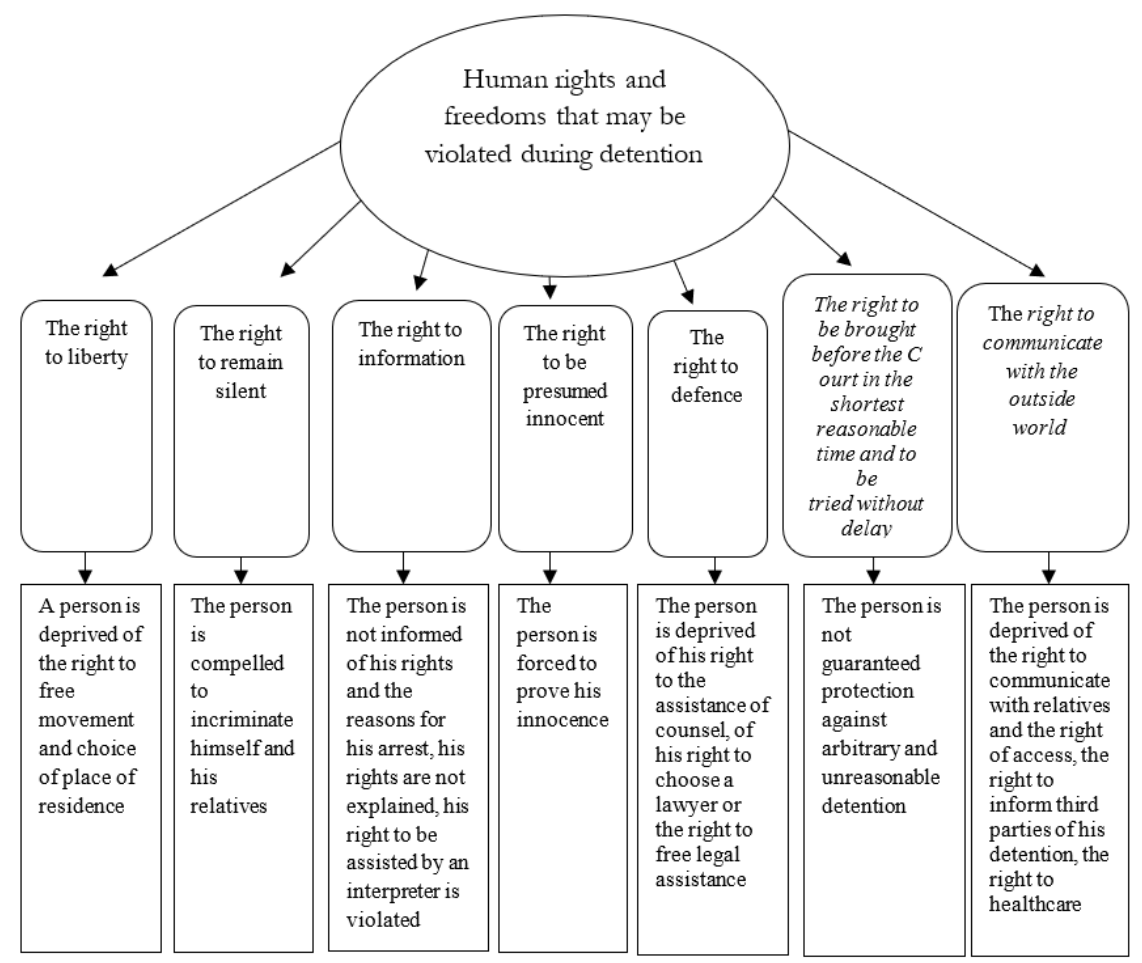

Source: own elaboration

All the afore-referenced rights and freedoms are clearly set forth in the Convention. During detention of a person first of all the provisions, enshrined in Article 5 of the Convention "Right to liberty and security", which guarantees that no one has the right to detain a person, to limit his rights, except the cases provided for by law, are violated. Along with this, the following rights are very often violated: the right, provided under Article 13 of the Convention "Right to an effective remedy", which guarantees the person the possibility of defending his rights and freedoms in case of their violation; provisions of Part 2 of Article 6 of the Convention, according to which a person accused of any crime shall be presumed innocent until proven guilty as prescribed by law and is not obliged to prove his innocence; the right to respect for private and family life, the right to housing and the right to correspondence, violation of which is permitted only in cases prescribed by law (Article 8 of the Convention) (Wikipedia, 2021). And 
Elizaveta Kuzmichova-Kyslenko, Maryna Horodetska, Iryna Smal, Dariia Hurina y Myroslav Pototskyi

650

Judicial Control over the Observance of Human Rights and Freedoms during the Detention of a Person

these provisions have been violated and, unfortunately, continue to be violated in many countries (see Tables 1-3).

Table 1. Number of appeals to the ECtHR (by articles of the Convention and by states) for 2018 (Violations by Article and by State, 2018)

\begin{tabular}{|c|c|c|c|c|}
\hline \multirow{2}{*}{ Country } & \multicolumn{4}{|c|}{ Number of Article of the Convention } \\
\cline { 2 - 5 } & 5 & 6 & 8 & 13 \\
\hline Albania & 1 & 0 & 0 & 0 \\
\hline Andorra & 0 & 0 & 0 & 0 \\
\hline Denmark & o & 0 & 0 & 0 \\
\hline Estonia & o & o & 1 & 0 \\
\hline Finland & o & 0 & 0 & 0 \\
\hline Iceland & 0 & 0 & 0 & 0 \\
\hline Ireland & 0 & 1 & 0 & 0 \\
\hline Liechtenstein & 0 & 0 & 0 & 0 \\
\hline Luxembourg & 1 & 1 & 0 & 0 \\
\hline Monaco & 0 & 0 & 0 & 0 \\
\hline Norway & 0 & 0 & 1 & 0 \\
\hline San Marino & 0 & 0 & 0 & 0 \\
\hline Sweden & 0 & 0 & 0 & 0 \\
\hline Armenia & 8 & 7 & 0 & 1 \\
\hline Bulgaria & 0 & 10 & 3 & 6 \\
\hline Greece & 6 & 11 & 1 & 12 \\
\hline Hungary & 2 & 11 & 2 & 6 \\
\hline Moldova & 14 & 5 & 2 & 6 \\
\hline Romania & 1 & 21 & 6 & 3 \\
\hline the Russian & 99 & 68 & 26 & 67 \\
\hline Federation & 29 & 53 & 8 & 7 \\
\hline Turkey & 45 & 63 & 12 & 37 \\
\hline Ukraine & & & & \\
\hline
\end{tabular}


Table 2. Number of appeals to the ECtHR (by articles of the Convention and by states) for 2019 (Violations by Article and by State, 2019)

\begin{tabular}{|c|c|c|c|c|}
\hline \multirow[t]{2}{*}{ Country } & \multicolumn{4}{|c|}{ Number of Article of the Convention } \\
\hline & 5 & 6 & 8 & 13 \\
\hline Albania & 0 & 0 & $\mathrm{o}$ & $\mathrm{O}$ \\
\hline Andorra & $\mathrm{o}$ & $\mathrm{o}$ & $\mathrm{O}$ & $\mathrm{O}$ \\
\hline Czech Republic & $\mathrm{O}$ & 0 & $\mathrm{O}$ & $\mathrm{O}$ \\
\hline Denmark & 1 & $\mathrm{O}$ & $\mathrm{o}$ & $\mathrm{O}$ \\
\hline Estonia & $\mathrm{O}$ & $\mathrm{o}$ & 1 & 1 \\
\hline Finland & o & $\mathrm{O}$ & $\mathrm{O}$ & $\mathrm{O}$ \\
\hline Germany & $\mathrm{O}$ & 0 & $\mathrm{O}$ & $\mathrm{O}$ \\
\hline Ireland & o & 1 & $\mathrm{O}$ & $\mathrm{O}$ \\
\hline Liechtenstein & 0 & 0 & $\mathrm{o}$ & 0 \\
\hline Luxembourg & 0 & 0 & $\mathrm{O}$ & $\mathrm{O}$ \\
\hline Monaco & $\mathrm{O}$ & $\mathrm{o}$ & $\mathrm{O}$ & $\mathrm{O}$ \\
\hline Netherlands & $\mathrm{o}$ & 1 & $\mathrm{O}$ & $\mathrm{O}$ \\
\hline San Marino & $\mathrm{O}$ & 1 & $\mathrm{O}$ & $\mathrm{O}$ \\
\hline Sweden & $\mathrm{o}$ & $\mathrm{o}$ & $\mathrm{O}$ & $\mathrm{O}$ \\
\hline Armenia & 0 & 5 & 2 & 3 \\
\hline Bulgaria & 0 & 4 & 2 & 5 \\
\hline France & $\mathrm{o}$ & 7 & 1 & 1 \\
\hline Greece & 5 & 10 & $\mathrm{O}$ & 7 \\
\hline Hungary & 5 & 27 & 1 & 16 \\
\hline Moldova & 9 & 27 & 4 & 3 \\
\hline Romania & 2 & 11 & 4 & $\mathrm{O}$ \\
\hline $\begin{array}{c}\text { Russian } \\
\text { Federation }\end{array}$ & 90 & 76 & 22 & 43 \\
\hline Turkey & 16 & 17 & 11 & 2 \\
\hline Ukraine & 54 & 58 & 9 & 38 \\
\hline
\end{tabular}


Elizaveta Kuzmichova-Kyslenko, Maryna Horodetska, Iryna Smal, Dariia Hurina y Myroslav Pototskyi

Table 3. Number of appeals to the ECtHR (by articles of the Convention and by states) for 2020 (Violations by Article and by State, 2020)

\begin{tabular}{|c|c|c|c|c|}
\hline \multirow[t]{2}{*}{ Country } & \multicolumn{4}{|c|}{ Number of Article of the Convention } \\
\hline & 5 & 6 & 8 & 13 \\
\hline Austria & $\mathrm{O}$ & $\mathrm{O}$ & $\mathrm{O}$ & $\mathrm{O}$ \\
\hline Andorra & $\mathrm{O}$ & $\mathrm{O}$ & $\mathrm{O}$ & $\mathrm{O}$ \\
\hline Cyprus & $\mathrm{O}$ & 1 & $\mathrm{O}$ & $\mathrm{O}$ \\
\hline Denmark & $\mathrm{O}$ & $\mathrm{O}$ & $\mathrm{O}$ & $\mathrm{O}$ \\
\hline Estonia & O & $\mathrm{O}$ & $\mathrm{O}$ & $\mathrm{O}$ \\
\hline Finland & $\mathrm{O}$ & $\mathrm{O}$ & $\mathrm{O}$ & $\mathrm{O}$ \\
\hline Ireland & O & 1 & $\mathrm{O}$ & O \\
\hline Liechtenstein & O & o & $\mathrm{O}$ & $\mathrm{O}$ \\
\hline Luxembourg & $\mathrm{O}$ & $\mathrm{O}$ & $\mathrm{O}$ & $\mathrm{O}$ \\
\hline Netherlands & $\mathrm{O}$ & $\mathrm{O}$ & $\mathrm{O}$ & $\mathrm{O}$ \\
\hline San Marino & O & 1 & o & O \\
\hline Sweden & O & o & $\mathrm{O}$ & $\mathrm{O}$ \\
\hline Armenia & 11 & 7 & $\mathrm{O}$ & $\mathrm{O}$ \\
\hline Azerbaijan & 17 & 21 & 10 & 1 \\
\hline Bulgaria & 6 & 4 & 7 & 3 \\
\hline Greece & 0 & 9 & 1 & 7 \\
\hline Hungary & 8 & 7 & 3 & 2 \\
\hline Moldova & 2 & 15 & 2 & 2 \\
\hline Romania & 1 & 14 & 10 & 3 \\
\hline $\begin{array}{l}\text { Russian } \\
\text { Federation }\end{array}$ & 82 & 63 & 24 & 27 \\
\hline Turkey & 16 & 24 & 11 & $\mathrm{O}$ \\
\hline Ukraine & 49 & 28 & 3 & 18 \\
\hline
\end{tabular}

These data show that the number of appeals to the ECtHR for individual countries remains stable (with minor changes). The number of human rights violations depends not so much on the socio-economic standard of living of people as on the level of democracy and ensuring the protection of the human rights in the country: the higher the effective protection of 
fundamental democratic principles, the fewer the number of appeals to the ECtHR is according to the specified norms. This shows that the number of violations of fundamental human rights and freedoms during the detention of a person is lower in such countries.

Without reference to the number of cases of violation of the provisions of the Convention, in the vast majority of states there is a special mechanism to ensure the protection of the rights of persons, detained on suspicion of having committed a crime. In much of the world, the investigating judge is the person, who monitors observance of human rights during detention. As a rule, the institution of judicial control itself, the investigating judge, his duties, as well as the grounds and mechanism of their performance are defined at the legislative level and enshrined in the form of norms in the national criminal procedure legislation (see Table 4).

Table 4. Norms of the criminal procedure legislation regulating the institute of the investigating judge (by states) (Cornell Law School, 2021)

\begin{tabular}{|c|l|}
\hline Country & \multicolumn{1}{|c|}{$\begin{array}{c}\text { Article regulating the exercise of } \\
\text { judicial control }\end{array}$} \\
\hline USA & the Fourth Amendment of "The Bill of Rights" \\
\hline France & Article 137 of the Penal Code \\
\hline England & Article 38 (4) of the Magistrates' Courts Act \\
\hline Germany & §115 of the Penal Code \\
\hline Ukraine & Article 206 of the Penal Code \\
\hline the Russian Federation & Article 165 of the Penal Code \\
\hline Kazakhstan & Article 54 of the Penal Code \\
\hline Moldova & Chapter VIII Article 300 of the Penal Code \\
\hline the Republic of & Article 289-290 of the Penal Code \\
\hline Macedonia & Article 65 of the Penal Code \\
\hline the Republic of Bulgaria & Section 3 Article 214 of the Penal Code \\
\hline Romania & Article 103, Article 109 of the Penal Code \\
\hline Turkey &
\end{tabular}

Instead, it should be noted that judicial control over the observance of human rights and freedoms during detention (as well as during other stages of the pre-trial investigation) is not provided for in the criminal legislation of Albania, Ireland, Liechtenstein, Croatia, the Czech Republic, Mongolia, and 
Elizaveta Kuzmichova-Kyslenko, Maryna Horodetska, Iryna Smal, Dariia Hurina y Myroslav Pototskyi

Saudi Arabia. In some countries, the function of control over the observance of human rights and freedoms during detention is entrusted to other penal procedure bodies: the prosecutor Netherlands (Criminal Procedure Code of the Kingdom of Netherlands, 2012), (Criminal Procedure Code of the Kingdom of Norway, 2013), the judicial police Bosnia and Herzegovina (Criminal Procedure Code of the Federation of Bosnia and Herzegovina, 2014).

Having regard to the number of appeals to the ECtHR, the rulings of the court, delivered by the ECtHR regarding human rights violations during the pre-trial investigations, including during detention, as well as control over the observance of human rights and freedoms in criminal proceedings, is the necessary step and an important function for ensuring person-centered administration of justice. Therefore, it has obviously become necessary to regulate statutorily judicial control in the national criminal procedural codes of as many countries as possible.

The need for judicial control over the observance of human rights during the detention of a person suspected of committing a crime is evidenced by the existing judgements of the ECtHR, delivered in cases of violation of human rights and freedoms under Articles 5, 6 and 13 of the Convention, which concern precisely the violation of the right to liberty and security, the right to a fair trial and the right to an effective remedy (see Table 5).

Table 5. Judicial decision of ECtHR on violations of human rights and freedoms provided for under Articles 5, 6 and 13 of the Convention (Hudoc, 2021)

\begin{tabular}{|c|c|}
\hline $\begin{array}{l}\text { Article of the } \\
\text { Convention }\end{array}$ & Decision of the European Court of Human Rights \\
\hline $\begin{array}{l}\text { Article } 5 \text { "Right } \\
\text { to liberty and } \\
\text { security" }\end{array}$ & 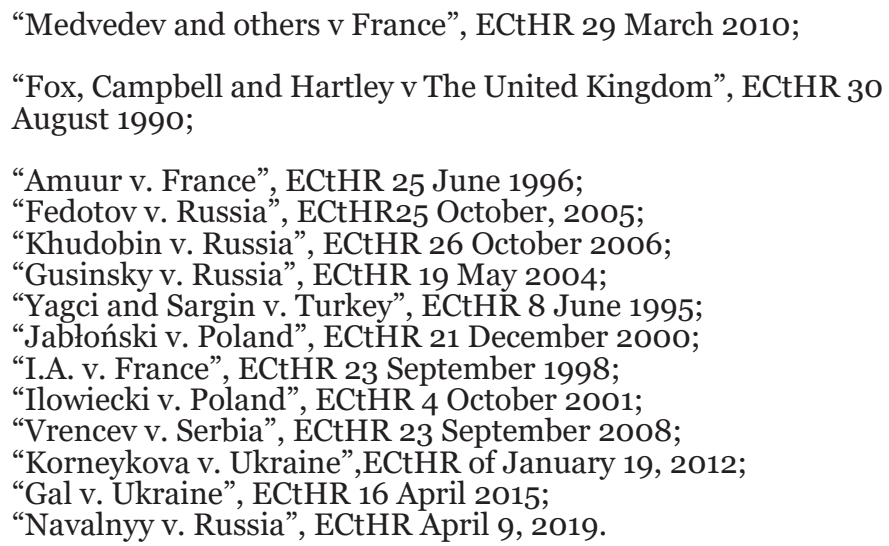 \\
\hline
\end{tabular}




\begin{tabular}{|l|l|}
\hline $\begin{array}{l}\text { Article 6 "The } \\
\text { right to a fair } \\
\text { trial" }\end{array}$ & $\begin{array}{l}\text { "Šubinski v. Slovenia", ECtHR 18 January 2007; } \\
\text { "Nakhmanovich v. Russia",ECtHR 2March, 2006; } \\
\text { "Kiryakov v. Ukraine", ECtHR 7 December 2006; } \\
\text { "Nakonechnyy v. Ukraine",ECtHR January 26, 2012; } \\
\text { "Yurtayev v. Ukraine, ECtHR 31 January 2006; } \\
\text { "Korneykova v. Ukraine", ECtHR 19January, 2012; } \\
\text { "Vera Fernández-Huidobro v.Spain", ECtHR 6 January 2010; } \\
\text { "Correia de Matos v. Portugal", ECtHR 4 April 2018; } \\
\text { "Lagerblom v. Sweden", ECtHR 14 January 2003 }\end{array}$ \\
\hline $\begin{array}{l}\text { Article 13 } \\
\text { "The right to } \\
\text { an effective } \\
\text { remedy" }\end{array}$ & $\begin{array}{l}\text { "Panteleyenko v. Ukraine", ECtHR 29 June 2006; } \\
\text { "Smith and Grady v. United Kingdom", ECtHR 27 September }\end{array}$ \\
\hline
\end{tabular}

Judicial control is a special type of procedural activities at the stage of pre-trial investigation, which in international law is called «Habeas Corpus Act» (Sereda, 2016). In essence, judicial control at the stage of detention of a person is a specific criminal procedure, aimed at ensuring respect for the fundamental rights and freedoms of a person, detained on suspicion of committing a crime, as well as ensuring redress for the violation of human rights and freedoms in case of their violation by authorized government bodies. The essence of judicial control is that it is the exercise of judicial power at the stages of pre-trial investigation, aimed at ensuring the lawfulness and compliance with the international legal principles of human rights protection during certain procedural actions. The ultimate purpose of judicial control is to ensure the principle of the rule of law, in particular at the stage of detention of a person.

Based on the provisions of the criminal procedure legislation, the function of judicial control over the observance of the rights of persons, detained on suspicion of committing a crime, is performed by various subjects- the investigating judge, the judicial police, the prosecutor. It would appear that the subject of this function should be the investigating judge, as conducting control over the observance of human rights and freedoms during pre-trial investigations reveals the legal nature of his activities. Instead, the legal nature of the prosecutor's work is the prosecution on behalf of the state or government, while the police, even the judicial police, are intended to perform law enforcement functions.

This position is confirmed by the fact that in the criminal procedure legislation of those countries, where the function of judicial control is provided, it is clearly defined that the investigating judge is the judge of the first-instance court, whose procedural duty, in accordance with the criminal procedure legislation, is to exercise judicial control over the 
Elizaveta Kuzmichova-Kyslenko, Maryna Horodetska, Iryna Smal, Dariia Hurina y Myroslav Pototskyi

observance of fundamental human rights and freedoms at all stages of criminal proceedings (Liga36o, 2012).

The institution of the investigating judge is relatively new in many countries, and therefore the attitude to the existence of such a specially authorized person, whose duty is to exercise judicial control over the observance of human rights and freedoms during his detention, is quite ambiguous. The reason for this is that, on the one hand, performing by the investigative judge of his procedural function of the observance of human rights and freedoms of the detainee in pre-trial investigations is in some cases excessively idealized and overemphasized.

Due to such inaccurate statements, judicial control is considered to be an absolutely impeccable guarantee of the legitimacy of criminal proceedings, especially with regard to certain investigative actions, such as the detention of a person on suspicion of committing a crime. In fact, it is not consistent with the reality, as judicial control is only an additional guarantee of respect for human rights and freedoms during detention, along with other subjects of criminal proceedings (the prosecutor, the judge, the defense counsel).

Judicial control, exercised by the investigating judge, takes place in the manner prescribed by law. According to the general provisions of international law, a detainee must be taken to court to verify the validity and lawfulness of his detention within 24hours of his detention. But a person must be brought before the court without undue delay so that the investigating judge would conduct control over the observance of human rights and freedoms of the detainee, which is emphasized in the criminal procedure laws of some countries (in particular, of Ukraine - Article 209 of the Penal Code of Ukraine). However, national criminal procedure laws rarely specify how the immediacy of taking a detainee to court should be understood. Therefore, it is appropriate to oblige national criminal procedure laws to regulate the period, during which a detainee should be brought before an investigating judge by stating "immediately, that is not later than 24 hours from the moment of detention". Such explicitation will reduce the risk of illegal administration of restrictions on persons who have been detained illegally, as well as will reduce the likelihood of further violation of their rights and freedoms.

Thus, in practice, there are often some difficulties with the implementation of this function, as judicial control over the observance of rights and freedoms during the detention of a person is conducted not in all cases. In particular, if a person is released without the prosecution appealing to the investigating judge in order to establish the lawfulness of detention, the released person will not be able to lodge a complaint of unlawful detention. Similarly, if judicial control is not exercised, even if the detention of a person is unlawful, the prejudicial inquiry of the case will be continued and the authorized bodies will proceed to the next stage - 
applying a measure of restraint. And in judicial proceedings on applying a measure of such restraint, the investigating judge will not always assess the lawfulness or unlawfulness of the person's detention. In order to avoid such a situation, that is, to ensure the restoration of the violated rights and freedoms of a person during detention, judicial control should be carried out automatically, without the necessity for a representative of any of the parties of the criminal proceedings to make appropriate submissions before the judge.

Disadvantages of carrying out judicial control may also be manifested in judicial malfeasances by the investigating judge and in certain risks on the part of a person detained on suspicion of committing a crime, which was discovered in the study after examining theoretical and empirical sources (see Figure 2).

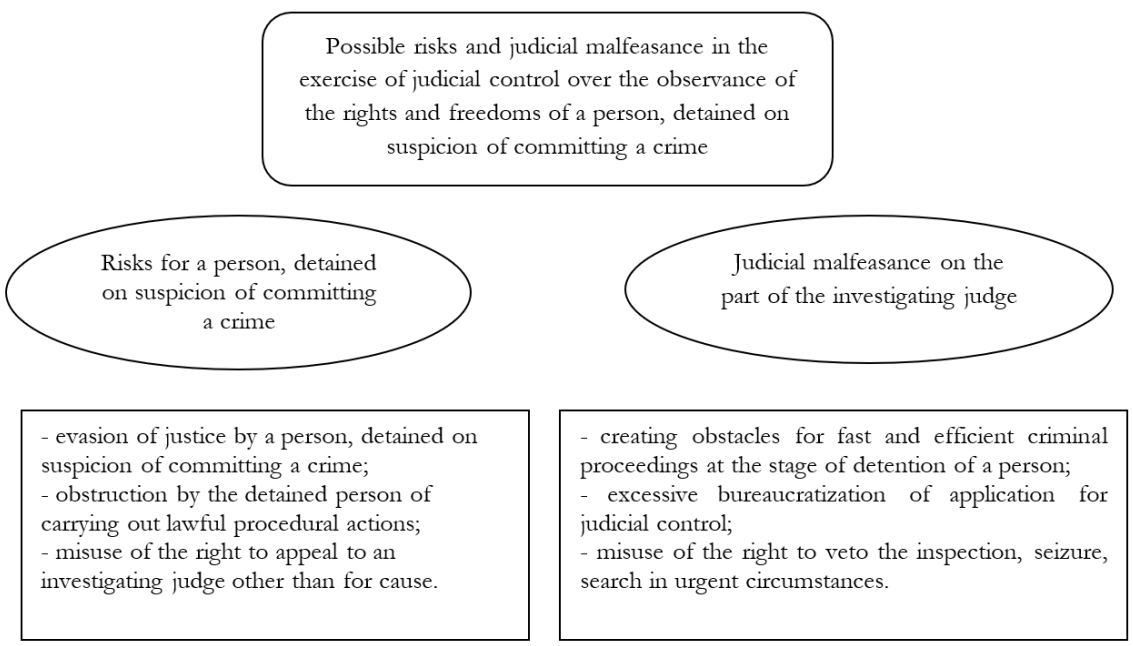

Figure 2. Risks of judicial malfeasance

Provision on the automatic exercise of judicial control over the observance of the rights and freedoms of a person, detained on suspicion of committing a crime, may help to avoid judicial malfeasance on the part of the investigating judge and the risks of illegal obstruction of justice by the detainee. It is also necessary to establish timelines after which the investigating judge must deliver informed judgement on the lawfulness/unlawfulness of the person's detention. This period may be up to 72 hours ( 3 days), during which the investigating judge, having studied the circumstances of the case, must make an informed judgement on lawfulness/unlawfulness of the detention of a person, suspected of committing a crime. 
Elizaveta Kuzmichova-Kyslenko, Maryna Horodetska, Iryna Smal, Dariia Hurina y Myroslav Pototskyi

Thus, the above mentioned indicates that the activities of the investigating judge on the control over the observance of rights and freedoms during the detention of a person are not devoid of difficulties and shortcomings. This is explained, first of all, by insufficient elaboration of the problem of improving statutorily regulation of the functioning of such a procedural institution. In order to eliminate the specified shortcomings and to universalize judicial control over the protection of human rights and freedoms during detention, it is necessary to develop an international normative legal document, which will be binding on all State Parties to this future document. It should regulate the concept, essence and principles of exercising judicial control and determine the parties to criminal proceedings that will exercise criminal justice.

The proposed document should include the following provisions:

- The concept of judicial control as specific criminal procedure, aimed at ensuring respect for the fundamental rights and freedoms of a person, detained on suspicion of committing a crime, as well as ensuring redress for the violation of human rights and freedoms in case of their violation by authorized government bodies.

- The subject of judicial control is the investigating judge.

- The principles of judicial control over the observance of human rights and freedoms during detention are immediacy (the detainee should be delivered to court within 24 hours of detention) and automaticity (judicial control over the lawfulness of detention of a person, suspected of committing a crime, should be carried out through making appropriate submissions before the judge by a representative of any of the parties to the criminal proceedings).

- Terms of judicial control and making an informed decision by the investigating judge should be defined as 72 hours (3 days), during which the investigating judge, having studied the circumstances of the case, has to make an informed judgement on lawfulness/ unlawfulness of the detention of a person suspected of committing a crime.

\section{Discussion}

The institution of an investigating judge is one of the guarantors of the observance of human rights and freedoms during detention of a person, which can at the same time be viewed as manifestation of the interaction between the court and the bodies of pre-trial investigation. That is why this institution is important and necessary in criminal proceedings. This view is confirmed by the exceptional importance of the rights and freedoms of a 
person (Nastiuk et al., 2020), which are ensured in the process of judicial control during the detention of a person. Moreover, it is noted that judicial control is the main guarantee of respect for the rights (Aljinovic, 2019) of persons detained on suspicion of committing a crime, as a separate type of defendants, as well as excessive interference with their rights. However, this is only one of the guarantees of observance of the rights of persons, detained on suspicion of committing crimes.

Although there is an opinion that the exercise of judicial control (Rossinskiy, 2017) in criminal proceedings is needless, as no special functional responsibilities are performed when carrying out judicial control. But it is difficult to agree with such a position, which is emphasized in the study of the role of the investigating judge in ensuring human rights in pre-trial proceedings (Kostin, 2015). In particular, this study underlines the effectiveness of judicial control over the observance of the rights and freedoms of detainees in the pre-trial investigation, in particular control over the actions of the prosecuting official (the prosecutor) (Nowak, 2014).

In some studies, the rights, and freedoms of a person, guaranteed by an investigating judge, include only the right to due process of law, the right to liberty and the right to property, which are considered to be the key rights in exercising judicial control (Bielousov et al., 2020). Although, in fact, during the detention of a person, and at other stages of the pre-trial investigation, other human rights (the right to information, the right to remain silent, etc.) are violated as well, as mentioned above.

The concept of judicial control is also defined in different ways. Thus, some studies state that pre-trial control consists exclusively in verifying the legality and validity of decisions on detention (arrest or keeping in custody) and in the elimination of wrongful incarceration of persons suspected of committing a crime (Khanov, 2017). However, most scholars yet recognize that judicial control is aimed precisely at protecting the fundamental human rights and freedoms of a person in criminal proceedings and ensuring their observance (Hinarejos, 2009).

The shortcomings, identified in the exercise by the investigating judge of judicial control over the observance of human rights and freedoms during detention indicate deficiencies in the mechanism for exercising judicial control. Therefore, it is impossible to consider this institution effective in the form in which it exists in some countries (Soo, 2018). Consequently, one cannot agree with excessive idealization and absolutization of judicial control in accordance with the current legislation in individual countries (Zinets, 2005).

Scientists have conducted very few researches in the criminal procedure law doctrine, dedicated to the improvement of the activities of the investigating judge in monitoring the observance of human rights and 
Elizaveta Kuzmichova-Kyslenko, Maryna Horodetska, Iryna Smal, Dariia Hurina y Myroslav Pototskyi

660

Judicial Control over the Observance of Human Rights and Freedoms during the Detention of a Person

freedoms in the pre-trial investigation. But even those few ones, that have been conducted, rarely offer specific means of increase of efficiency and improvement, but only identify shortcomings and problems in the exercise of judicial control by the investigating judge (Trukšāne, 2020). And the few studies that contain practical recommendations, as a rule, relate only to national legislation and do not go beyond the native country of the researcher (Bortun, 2018). Instead, international law contains a number of normative legal acts that elaborate on the procedure for ensuring human rights and freedoms during the detention of a person (Pivaty and Soo, 2019), which indicates the importance of eliminating shortcomings in the exercise of judicial control in this area at the international level. Improving the conduct of judicial control over the observance of rights and freedoms during the detention of a person may become a prospect of further research in this field of study.

\section{Conclusions}

The institution of an investigating judge is one of the guarantors of respect for human rights and freedoms during detention of a person, which at the same time can be seen as manifestation of the interaction between the bodies of pre-trial investigation and the court. Consequently, this institution is important and necessary in criminal proceedings.

Judicial control at the stage of detention of a person is a specific criminal procedure, aimed at ensuring respect for the fundamental rights and freedoms of a person detained on suspicion of committing a crime, as well as ensuring redress for the violation of human rights and freedoms in case of their violation by authorized government bodies.

The subject of this function should be an investigating judge - a judge of the first-instance court, whose procedural duty, in accordance with the criminal procedure legislation, is to exercise judicial control over the observance of fundamental human rights and freedoms at all stages of criminal proceedings.

Judicial control must be exercised in accordance with the following principles: the detainee should be delivered to the investigating judge immediately, not later than 24 hours from the moment of detention; judicial control should be exercised automatically, without the obligatory request of a representative of any of the parties to the criminal proceedings; the investigating judge, having studied the circumstances of the case, must within 72 hours (3 days) deliver informed judgement on the lawfulness/ unlawfulness of the detention of a person suspected of committing a crime. 
In order to eliminate shortcomings and universalize judicial control over the protection of human rights and freedoms during detention, it is necessary to develop an international normative legal document, which will be binding on all State Parties to this future document and will regulate the concept, essence and principles of exercising judicial control and determine the parties to criminal proceedings that will exercise criminal justice.

This study opens the prospects of developing the most effective model of procedural activity of an investigating judge and implementation of the function of judicial control over the observance of human rights and freedoms of a person detained on suspicion of committing a crime in criminal proceedings in general on the basis of further collection of statistics on individual countries on the number of violations of human rights and freedoms during detention and on the number of appeals to the European Court of Human Rights.

\section{Bibliographic References}

ALJINOVIC, Nevena. 2019. "Special Evidentiary Actions in the Context of Judicial Control of their Application in Practice in the Republic of Croatia" In: 44th International Scientific Conference on Economic and Social Development - Split, 19-20 September 2019, pp. 69-80.

ALLEGREZZA, Silvia; COVOLO, Valentina. 2013. "The directive 2012/13/EU on the right to information in criminal proceedings: status quo or step forward?" In: EU Pravo. Available online. In: https://eu.pravo.hr/_ download/repository/3_-_The_Directive_201213EU_on_the_Right_ to_Information_in_Criminal_Proceedings--_status_quo_or_step_ forward.pdf. Date of consultation: 17/03/2020.

BAKYT, Aidar. 2016. "Authorization of the Barring Order by the Investigating Judge: Problems of Legislative Regulation" In: Journal of Advanced Research in Law and Economics (JARLE). Vol. 7, No. 19, pp. 989-994.

BIELOUSOV, Yuriy; VENGER, Volodymyr; ORLEAN, Andriy; KRAPYVIN, Yevgen; SHAPUTKO, Svitlana; YAVORSKA, Vasylyna. 2020. The Role of the Court in Criminal Proceeding. Publisher Klymenko Yu. Ya. Kyiv, Ukraine.

BILLING, Fenella. 2016. The Right to Silence in Transnational Criminal Proceedings: Comparative Law Perspectives. Springer International Publishing. Switzerland, Ginevra.

BORTUN, Mykola. 2018. "Ensuring the Effectiveness of a Pre-trial Investigation under Current Circumstances" In: Visnyk NAPU. Vol. 2, pp. 46-57. 
Elizaveta Kuzmichova-Kyslenko, Maryna Horodetska, Iryna Smal, Dariia Hurina y Myroslav Pototskyi

662

Judicial Control over the Observance of Human Rights and Freedoms during the Detention of a Person

BRANTS, Chrisje; FRANKEN, Sitjn. 2009. "The protection of fundamental human rights in criminal process General report" In: Utrecht Law Review. Vol. 5, No. 2, pp. 7-65.

CORNELL LAW SCHOOL. 2021. Fourth Amendment. U.S. Constitution Annotated Toolbox. In: Legal Information Institute. Available online. In: https://www.law.cornell.edu/constitution-conan/amendment-4. Date of consultation: 17/03/2021.

CRIMINAL PROCEDURE CODE OF THE FEDERATION OF BOSNIA AND HERZEGOVINA. 2014. In: Legislati online. Available online. In: https://www.legislationline.org/download/id/8503/file/CPC_FBiH_ am2014_eng.pdf. Date of consultation: 17/03/2021.

CRIMINAL PROCEDURE CODE OF THE KINGDOM OF NETHERLANDS. 2012. In: Legislati online. Available online. In: https://www. legislationline.org/download/id/6416/file/Netherlands_CPC_ am2012_en.pdf. Date of consultation: 17/03/2021.

CRIMINAL PROCEDURE CODE OF THE KINGDOM OF NORWAY. 2013. In: Legislati online. Available online. In: https://www.legislationline. org/download/id/8290/file/Norway_Criminal_Procedure_Act_1981_ am2013_en.pdf. Date of consultation: 17/03/2021.

ĐURĐEVIĆ, Zlata. 2016. The directive on the right of access to a lawyer in criminal proceedings: filling a human rights gap in the European Union Legal Order. Edited by Đurđević Zlata, Ivičević Karas. In: European Criminal Procedure Law in Service of Protection of European Union Financial Interests: State of Play and Challenges, pp. 9-25. Association of European Criminal Law. Zagreb, Croatian

HINAREJOS, Alicia. 2009. Judicial control in the European Union: Reforming jurisdiction in the intergovernmental pillars. Oxford University Press. New York, USA.

HUDOC. 2021. European Court of Human Rights. Available online. In: https:// hudoc.echr.coe.int/Eng\#\%20. Date of consultation: 17/02/2021.

JACKSON, John; SUMMERS, Sarah. 2018. Obstacles to fairness in criminal proceedings: individual rights and institutional forms. Hart Publishing. Portland-Oregon, USA.

KHANOV, Talhat. 2017. "Judicial control over ensuring the rights of the individual during the pre-trial investigation" In: KEU Bulletin, Economics, Philosophy, Pedagogy, Jurisprudence. Available online. In: https://articlekz.com/article/27815. Date of consultation: 17/02/2021. 
KOSTIN, Mykhailo. 2015. The role of investigative judge in ensuring the right of a person to launch the pre-trial investigation. In: Bulletin of the High Qualification Commission of Judges of Ukraine. Available online. In: https://webcache.googleusercontent.com/ search?q=cache:zdDQoNRZZ34J:https://www.vkksu.gov.ua/ua/ about/visnik-vishoi-kvalifikatsiynoi-komisii-suddiv-ukraini/the-roleof-investigative-judge-in-ensuring-the-right-of-a-person-to-launchthe-pre-trial-investigation $/+\& c d=1 \& h l=r u \& c t=c \operatorname{lnk} \& g l=u a . \quad$ Date $\quad$ of consultation: 17/10/2020.

LANDINA, Anna. 2017. "Ensuring the right of the subject of the crime by the principles of criminal law" In: Judicial appeal. Vol. 1, pp. 66-73. Available online. In: http://nbuv.gov.ua/UJRN/Suap_2017_1_11. April 15, 2021. Date of consultation: 17/03/2020.

LIGA 360. 2012. The investigating judge. In: Ligazakon. Available online. In: https://ips.ligazakon.net/document/TMo44324. Date of consultation: 17/03/2020.

MITSILEGAS, Valsamis. 2019. "The European Union and the Rights of Individuals in Criminal Proceedings." Edited by: D. K. Brown, J. I. Turner, B. Weisser. In: The Oxford Handbook of Criminal Process. Oxford, Oxford University Press.

MUZYCHENKO, T. O. 2017. Institute of Appeal the Investigating Judge's Ruling, that Restricts Right of Ownership during the Pretrial Investigation: Concept, Features and Value. In: Sciences of Europe. Vol. 13, No. 4, pp. 100-103.

NAGY, Sarah. 2016. "Use and Abuse of Pre-Trial Detention in Council of Europe States: A Path to Reform" In: Loyola University Chicago International Law Review. Vol. 13, No. 2. Available online. In: https://lawecommons. luc.edu/lucilr/vol13/iss2/6. Date of consultation: 17/10/2020.

NASTIUK, Vasyl; MIKHAILOV, Oleksandr; IZBASH, Ekaterina; KONDRATENKO, Vitalii. 2020. "Judicial control over investigative (search) actions that require prior permission" In: Amazonia Investiga. Vol. 9, No. 28, pp. 151-158. Available online. In: http://dx.doi. org/10.34069/AI/2020.28.04.18. Date of consultation: 17/10/2020.

NOWAK, Celina. 2014. "Judicial Control of the Prosecutors' Activities in the Light of the ECHR” In: EUCRIM. Vol. 2, pp. 60-63.

PENAL CODE OF UKRAINE. 2001. Available online. In: https://www. legislationline.org/documents/action/popup/id/16257/preview. Date of consultation: 17/03/2020. 
Elizaveta Kuzmichova-Kyslenko, Maryna Horodetska, Iryna Smal, Dariia Hurina y Myroslav Pototskyi

664

Judicial Control over the Observance of Human Rights and Freedoms during the Detention of a Person

PIVATY, Anna; SOO, Anneli. 2019. "Article 7 of the Directive 2012/13/EU on the Right to Information in Criminal Proceedings: A Missed Opportunity to Ensure Equality of Arms in Pre-Trial Proceedings?” In: European Journal of Crime, Criminal Law and Criminal Justice. Vol. 27, No. 2, pp. 126-154.

RADIĆ, Ivana. 2018. "Right of the child to information according to the directive 2016/800/EU on procedural safeguards for children who are suspects or accused persons in criminal proceedings" In: EU and Comparative Law Issues and Challenges Series (ECLIC). Vol. 2, pp. 468-491. Available online. In: https://doi.org/10.25234/eclic/7122. Date of consultation: $17 / 10 / 2020$.

REN, Shuai-jun. 2017. "On the Value of Human Rights in the Socialist Core Values" In: Journal of Wuhan University of Technology (Social Sciences Edition).Vol. 6. Available online.In: https://en.cnki.com.cn/Article_en/ CJFDTotal-WHJT201706007.html. Date of consultation: 17/03/2021.

ROSSINSKIY, S. B. 2017. "Reflections on the efficiency of judicial control over the production of investigative actions" In: Tomsk State University Bulletin. Vol. 423, pp. 225-235.

SEREDA, K. 2016. "Habeas Corpus Act" procedure for compliance of domestic legal regulation with international standards" In: Scientific Bulletin of Uzhhorod National University. Vol. 41, No. 2, pp. 177-180.

SHARENKO, Svitlana. 2020. "Problematic Issues of the Activity of the Investigating Judge in Executing Judicial Control for the Protection of Human Rights" In: Law of Ukraine. Vol. 256. Available online. In: https://heinonline.org/HOL/LandingPage?handle=hein.journals/ lawukrai2020\&div=210\&id=\&page $=$. Date of consultation: 17/03/2021.

SOO, Anneli. 2016. "Potential Remedies for Violation of the Right to Counsel in Criminal Proceedings: Article 12 of the Directive 2013/48/EU (22 October2013) and its Output in National Legislation" In: European Criminal Law Review. Vol. 6, pp. 284-307. Available online. In: https://doi.org/10.5771/2193-5505-2016-3-284. Date of consultation: 17/03/2021.

SOO, Anneli. 2018. "(Effective) Remedies for a Violation of the Right to Counsel During Criminal Proceedings in the European Union: An Empirical Study” In: Utrecht Law Review. Vol. 14, No. 1, pp. 18-6o.

TRUKŠĀNE, Zane. 2020. "Limits of competence of an investigating judge in the pre-trial criminal proceedings. Individual. Society" In: State. Proceedings of the International Student and Teacher Scientific and 
Practical Conference. Available online. In: https://doi.org/10.17770/ iss2019.5298. Date of consultation: 17/03/2021.

UNITED NATIONS. 2021. Universal Declaration of Human Rights. Available online. In: https://www.un.org/en/about-us/universal-declaration-ofhuman-rights. Date of consultation: 17/03/2021.

VIOLATIONS BY ARTICLE AND BY STATE. 2018. In: ECHR. Available online. In: https://www.echr.coe.int/Documents/Stats_violation_2018_ENG. pdf. Date of consultation: 17/03/2021.

VIOLATIONS BY ARTICLE AND BY STATE. 2019. In: ECHR. Available online. In: https://www.echr.coe.int/Documents/Stats_violation_2019_ENG. pdf. Date of consultation: 17/03/2021.

VIOLATIONS BY ARTICLE AND BY STATE. 2020. In ECHR. Available online. In: https://www.echr.coe.int/Documents/Stats_violation_2020_ENG. pdf. Date of consultation: 17/03/2021.

WIKIPEDIA. 2021. Convention for the Protection of Human Rights and Fundamental Freedoms. Available online. In: https://en.wikipedia.org/ wiki/European_Convention_on_Human_Rights. April 15, 2021. Date of consultation: 17/03/2021.

YEDNAK, Viacheslav; VITIUK, Dariya; KRUT, Kateryna; GROKHOLSKYI, Vadym. 2020. "Ensuring the Rights of the Person When Notifying of Suspicion or Detention on Suspicion of Committing a Criminal Offense" In: Amazonia Investiga. Vol. 9, No. 25, pp. 423-428.

ZINETS, R. A. 2005. Judicial control at the stage of preliminary investigation: procedural and organizational aspects. [PhD Thesis]. Volgograd, VA Ministry of Internal Affairs of Russia. Moscow, Russia. 

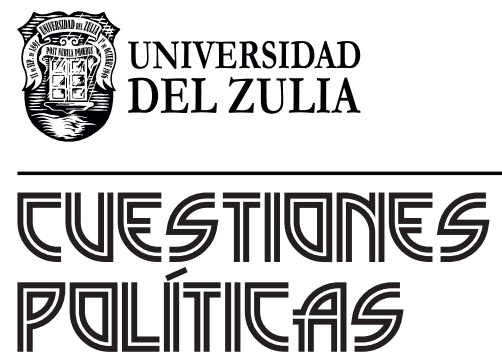

Vol.39 No 69

Esta revista fue editada en formato digital y publicada en julio de 2021, por el Fondo Editorial Serbiluz, Universidad del Zulia. Maracaibo-Venezuela 